\title{
The evidence of metamery in adult brachiopods and phoronids
}

\author{
Elena N. Temereva ${ }^{1}$, Vladimir V. Malakhov ${ }^{1,2}$ \\ ${ }^{1}$ Department of Invertebrate Zoology, Biological Faculty, Moscow State University, \\ Moscow 119992, Russia. \\ e-mail:temereva@mail.ru \\ ${ }^{2}$ Laboratory of Biology of Marine Invertebrates, Far East Federal University, Vladivostok \\ 690014, Russia.
}

ABSTRACT: There are both metameric and nonmetameric animal body plans in each of the three main branches of the bilaterian tree - the Ecdysozoa, the Deuterostomia and the Lophotrochozoa. Has metamery originated independently in these groups or is it a synapomorphy of all Bilateria? If the latter is correct, we might expect to find remnants of metamery in nonmetameric forms. The Lophophorata seems to be the only group of main bilaterian groups that lacks metamery. Here, we infer that the lateral mesenteries of brachiopods and phoronids are metameric in nature and originated from dissepiments between segments of trunk coelomic sacks of an oligomerous ancestor. In addition to preoral and lophophore coeloms, brachiopods and phoronids demonstrate a metameric subdivision of the body coelom. The trunk coelom of recent brachiopods and phoronids is a product of partial fusion of three or two segments, respectively. The lateral mesenteries in phoronids and brachiopods bear funnels of excretory organs like the dissepiments of true metameric animals (for example, annelids). In both groups, the lateral mesenteries are situated at an angle to the main axis of the body and always at a right angle to the axis of metamery. We conclude that metamery was present in ancestral Lophrophotrochozoans and in the common ancestor of all Bilateria but has since been reduced in some groups. The reduction of metamery in phoronids and brachiopods is correlated with strong changes in their body plan. We suggest that lophophorates are primitive lophotrochozoans because they retained some plesiomorphic features.

KEY WORDS: Lophotrochozoa, phylogeny, lateral mesenteries, metamorphosis, body plan.

\section{Доказательства существования метамерии у форонид и брахиопод}

\section{Е.Н. Темерева1, В.В. Малахов ${ }^{1,2}$}

\author{
${ }^{1}$ Биологический факультет Московского государственного университета им. М.В. \\ Ломоносова, Москва 119991, Россия. \\ e-mail: temereva@mail.ru \\ 2 Лаборатория биологии морских беспозвоночных, Дальневосточный федеральный \\ университет, Владивосток 690014, Россия.
}


РЕЗЮМЕ: Метамерные и неметамерные представители могут быть обнаружены во всех трех главных группах Bilateria: Ecdysozoa, Deuterostomia, Lophotrochozoa. Произошла ли метамерия независимо во всех трех главных группах или же метамерия это синапомрфия всех Bilateria? Если последние утверждение верно, то мы могли бы ожидать обнаружение метамерии у неметамерных организмов. Lophophorata кажутся единственной крупной группой билатерально-симметричных организмов, у представителей которой метамерия отсутствует. В настоящей работе мы утверждаем, что латеральные мезентерии форонид и брахиопод имеют метамерную природу и происходят от диссепиментов между туловищными сегментами олигомерного предка. Кроме предротового и постротового целомов у форонид и брахиопод имеется метамерный туловищный целом, который у современных форм представляет собой продукт частичного слияния целомических мешков двух (у форонид) или трех (у брахиопод) сегментов. Латеральные мезентерии форонид и брахиопод несут воронки выделительных органов как это характерно для диссепиментов настоящих метамерных животных (например, кольчатых червей). И у фороинд, и убрахиопод латеральные мезентерии располагаются под углом к главной оси тела и под прямым углом к оси метамерии. Можно заключить, что метамерия присутствовала у предков Lophrophotrochozoa, а так же и у общего предка Bilateria, но была утеряна в некоторых группах. Редукция метамерии у форонид и брахиопод связана с сильным изменением плана строения этих животных. Мы предполагаем, что лофофораты это наиболее примитивные Lophrophotrochozoa, поскольку они сохранили многие плезиоморфные черты строения и развития.

КЛЮЧЕВЫЕ СЛОВА: Lophotrochozoa, филогения, латеральные мезентерии, метаморфоз, план строения.

\section{Introduction}

Many publications over the last 15 years strongly support the view that Bilateria consist of three groups: the Lophotrochozoa, the Ecdysozoa, and the Deuterostomia (Zravý et al., 1998; Adoutte et al,. 2000; Halanych, Passamaneck, 2001; Peterson, Eernisse, 2001; Giribet, 2002; Balavoine, Adoutte, 2003; Halanych, 2004; Telford, 2006; Dun et al., 2008; Paps et al., 2009). Despite controversy about the specific position of some taxa, these major groups now seem to be well established and are frequently recovered in analyses of data sets derived from ribosomal RNAs, mitochondrial genomes, and ESTs. The classical view that the Lophophorata is closely related to the Deuterostomia is still discussed but has increasingly been challenged based on morphology and molecular phylogeny (see Cohen, 2000; Cohen, Weydmann, 2005; Lüter, 2000, 2004; Lüter, Bartolomaeus, 1997;
Adoutte et al., 2000; Giribet et al., 2000; Nesnidal et al., 2010). According to recent ideas on animal phylogeny, the Lophophorata and Trochozoa are two closely related animal groups forming the taxon Lophotrochozoa (Halanych et al., 1995; Helfenbein, Boore, 2004; Helmkampf et al., 2008; Giribet, 2008). Moreover, all three phyla of lophophorates (the Phoronida, the Bryoza, and the Brachiopoda) are currently thought to be included in the Trochozoa (Dun et al., 2008; Giribet, 2008; Paps et al., 2010).

Metamery is clearly pronounced in many groups within the Ecdysozoa (e.g., Arthropoda and Lobopoda) and the Deuterostomia (e.g., Chordata). Among the Lophotrochozoa, some groups of typical trochozoan (annelids, for example) exhibit classical metamery, while others (e.g., mollusks, echiurids, and sipunculids) demonstrate more or less well-expressed traces of ancestral metamery (Hessling,Westheide, 2002; Kristof et al., 2008; Wanninger, 2009). 
In understanding of the origin of metamery in these groups, we must choose between two hypotheses. The first hypothesis is that in animal evolution metamery originated three times independently. The alternative hypothesis is that the common bilaterian ancestor possessed metamery and that some animal groups lost metamery during further evolution. The second hypothesis seems more plausible than the first.

Lophophorata seems to be the only group that lacks metamery. In classical zoology, the Lophophorata is regarded as an archicoelomate group that has archimery instead of metamery (Masterman, 1898; Remane, 1949; Ulrich, 1951; Siewing, 1980). The search for traces of metamery in lophophorates is important because the detection of such traces would confirm the hypothesis concerning the primary metamery of Bilateria.

Nielsen (1991) demonstrated that the larva of the brachiopod Neocrania, which is in the Lophophorata, has three pairs of setae bundles arranged metamerically. Until now, this is the only unquestionable example of metamery in lophophorates. Adult brachiopods and phoronids have no definite signs of metamery. The main purpose of this publication is to reveal the traces of the ancestral metamery in the structure of brachiopods and phoronids and suggest a hypothesis concerning the origin of their sophisticated body plans.

\section{Metamery in brachiopods}

Among all brachiopods, metamery is expressed most in the larva of Neocrania. According to Nielsen (1991), the larva of Neocrania has external and internal metamery. Externally, the larva has three pairs of setae pouches (Fig. 1A). It is well known that, among all Bilateria, only brachiopods and annelids have setae with defined ultrastructure. In Neocrania larvae, Nielsen (1996) described an unpaired anterior coelom and three pairs of coelomic sacks corresponding to three pairs of setae pouches (Fig. 1A). Other authors suggested that the three pairs of sacks are not coelomic sacks but are setae pouch muscles (Altenburger, Wanninger, 2010).
Nevertheless, no researcher has denied the occurrence of metamery in the organization of Neocrania larvae. According to Nielsen(1991), the Neocrania larva at metamorphosis curls ventrally by contraction of a pair of midventral muscles, which are extensions of the first pair of coelomic sacks (Fig. 1A). The anterior-posterior axis of the larva curves. Both valves of the adult originate from dorsal epithelial areas of the larva. The brachial valve is secreted by the middle part of the dorsal epithelium, and the pedicle valve is secreted by the attachment epithelium. Nielsen (1991) suggested that metamorphosis of Neocrania recapitulates origin of the body plan of all brachiopods, i.e., recent brachiopods fold on the ventral side. Acceptance of this idea facilitates the detection of metamery in adult brachiopods.

The coelom of adult brachiopods has a complex organization. Adult brachipods have large and small sinuses of the lophophore, a pereisophageal coelom associated with the small sinus of lophophore, and a voluminous trunk coelom that penetrates into the mantle (Hancock, 1859; Blochmann, 1892; Blochmann, 1900; James, 1997; Williams et al., 1997; Kuzmina et al., 2006; Kuzmina, Malakhov, 2011). The dorso-ventral mesentery divides the trunk coelom into left and right parts. Most brachiopods have two pairs of incomplete lateral mesenteries (Fig. 1B). They are called the gastroparietal and ileoparietal mesentery. Novocrania have only ileoparietal mesentery. The origin of the lateral mesenteries in brachiopods is unknown. Three-dimensional reconstruction of the lateral mesenteries reveals that they pass at an angle to each other (Fig. 1B) (Malakhov, Kuzmina, 2006). If one accepts that the anterior-posterior axis of the brachiopod is curved (as it is in metamorphosis) (Fig. 1C), then the lateral mesenteries are located like dissepiments between segments. If lateral mesenteries correspond to dissepiments, three trunkal segments that partly fused form the trunk coelom. Interestingly, this number (three) agrees with number of segments in Neocrania larvae.

In typical metameric animals like annelids, the dissepiments bear the funnels of the nephrid- 


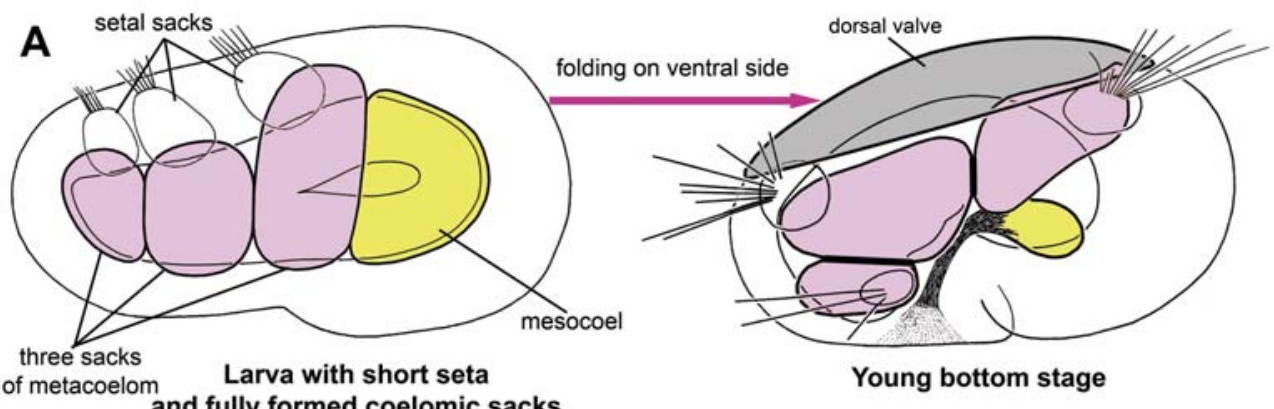

of metacoelom and fully formed coelomic sacks

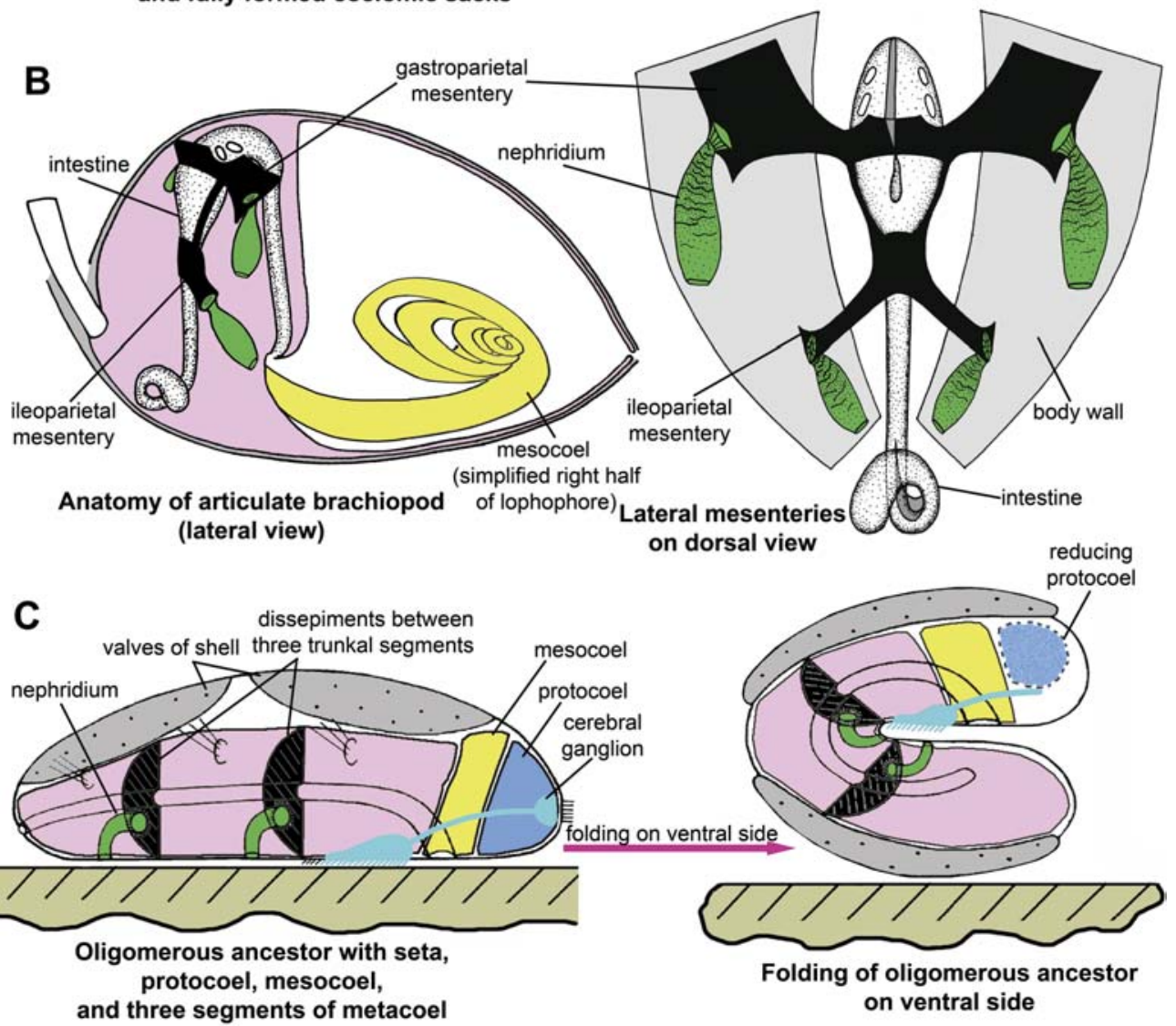

Fig. 1. Metamery in brachiopods.

A - The organization and metamorphosis of a Neocrania anomala larva according to Nielsen (1991) with changes; $\mathrm{B}$ - The arrangement of lateral mesenteries in adult articulate brachiopods (Hemithyris psittacea): dorsal and side views according to Malakhov, Kuzmina (2006) with changes; C - The origin of the brachiopod body plan in evolution. Рис. 1. Метамерия у брахиопод.

A - Организация и метаморфоз личинки Neocrania anomala по данным Nielsen (1991) с изменениями; В Расположение латеральных мезентериев у взрослых современных брахиопод (Hemithyris psittacea): вид с дорсальной и латеральной сторон по Malakhov, Kuzmina (2006) с изменениями; C — происхождение плана строения брахиопод в эволюции. 
ia. Primitive articulated brachiopods, the Rhynchonellida, have two pairs of nephridial funnels that open on the gastroparietal and ileoparietal mesenteries (Fig. 1B). Brachiopods from Discinisca have two pairs of gonads: one connects with the gastroparietal mesentery, and the other connects with the ileoparietal mesentery (Hyman, 1959). These findings demonstrate that adult brachiopods maintain metamery, but that the metamery is masked by the curvature of the anterior-posterior axis. It is important to note that Gutmann and his coauthors (1978) were the first to suggest that brachiopods exhibit metamery. These authors homologized lateral mesenteries of Lingula with dissepiments. At that time, however, it was not yet known that the anterior-posterior axis of brachiopods curves during metamorphosis. Gutmann et al. (1978) inferred that the anterior-posterior axis (the axis of metamery) of adult brachiopods passes along the axis of the pedicel of Lingula.

Thus, we can find three segments in adult brachiopods (Fig. 1C), and these segments do not include the lophophore and associated coeloms (large and small sinuses). Some typical trochozoans such as Canalipalpata polychaetes have a tentacular coelom, which is usually not included in the counting of trunkal segments (Rouse, Fauchald, 1997). It is conceivable that the lophophoral coelom of brachiopods is a homologue of the tentacular coelom of Canalipalpata polychaetes.

\section{Metamery in phoronids}

Until recently, phoronids were considered to be typical archimeric (but not metameric) animals. This opinion was based on results of Masterman (1898) who described three coelomic compartments in phoronids: unpaired preoral, paired tentacular, and paired trunkal compartments. Subsequently, these results were corrected when researchers determined that phoronid larvae have unpaired preoral, unpaired tentacular, and unpaired trunk coeloms (Menon, 1902; Goodrich, 1903; Cowles, 1904). New data on the organization of the coelomic system of phoronid larvae were then obtained by transmission electron microscopy, which was a novel method at that time (Bartolomaeus, 2001). According these new results, phoronid larvae of Phoronis muelleri have tentacular and trunk coeloms but do not have a preoral coelom. In our recent work (Temereva, Malakhov, 2006), we showed that larvae of Phoronopsis harmeri have three coeloms: preoral, tentacular, and trunkal(Fig. 2A, B). Thus, phoronid larvae have two types of coelomic system organization. This is also true for adult phoronids. For example, Phoronis ovalis lacks the preoral coelom (coelom of the epistome) (Gruchl et al., 2005), whereas Phoronopsis harmeri has a distinct preoral coelom inside the epistome (Temereva, Malakhov, 2011). Thus, two patterns of organization for the coelomic system occur among adult phoronids. The first pattern - the bipartite coelom - is found in specimens of the genus Phoronis, which have two coelomic compartments: the mesocoel (the tentacular or lophophoral coelom) and the metacoel (the trunk coelom). The second pattern - the tripartite coelom — is found in specimens of the genus Phoronopsis, which have three coelomic compartments: the protocoel, mesocoel, and metacoel. Nevertheless, no authors have considered that larvae or adult phoronids have true metamery.

Metamorphosis in phoronids differs from metamorphosis in brachiopods (Fig. 3) (Kovalevsky, 1867; Siewing, 1974; Herrmann, 1979; Temereva, 2010). In the young larval stage of phoronids, the metasomal sack forms on the ventral body side under the tentacles (Fig. 3B, C) (Temereva, Malakhov, 2007). The metasomal sack is an invagination of the body wall ectoderm into the trunk coelom (Fig. 2B). In competent larvae, the metasomal sack becomes voluminous and long (Fig. 2C). Phoronid metamorphosis begins with evagination of the metasomal sack (Fig. 3B, C). Simultaneously, the digestive tract attached to the metasomal sack by ventral mesentery draws down. Together with the digestive tract, other organs (the blood system and nephridia) draw down into the inverted metasomal sack. The terminal part of the metasomal sack moves constantly; it becomes swollen and spherical (Fig. 3D) and then trans- 

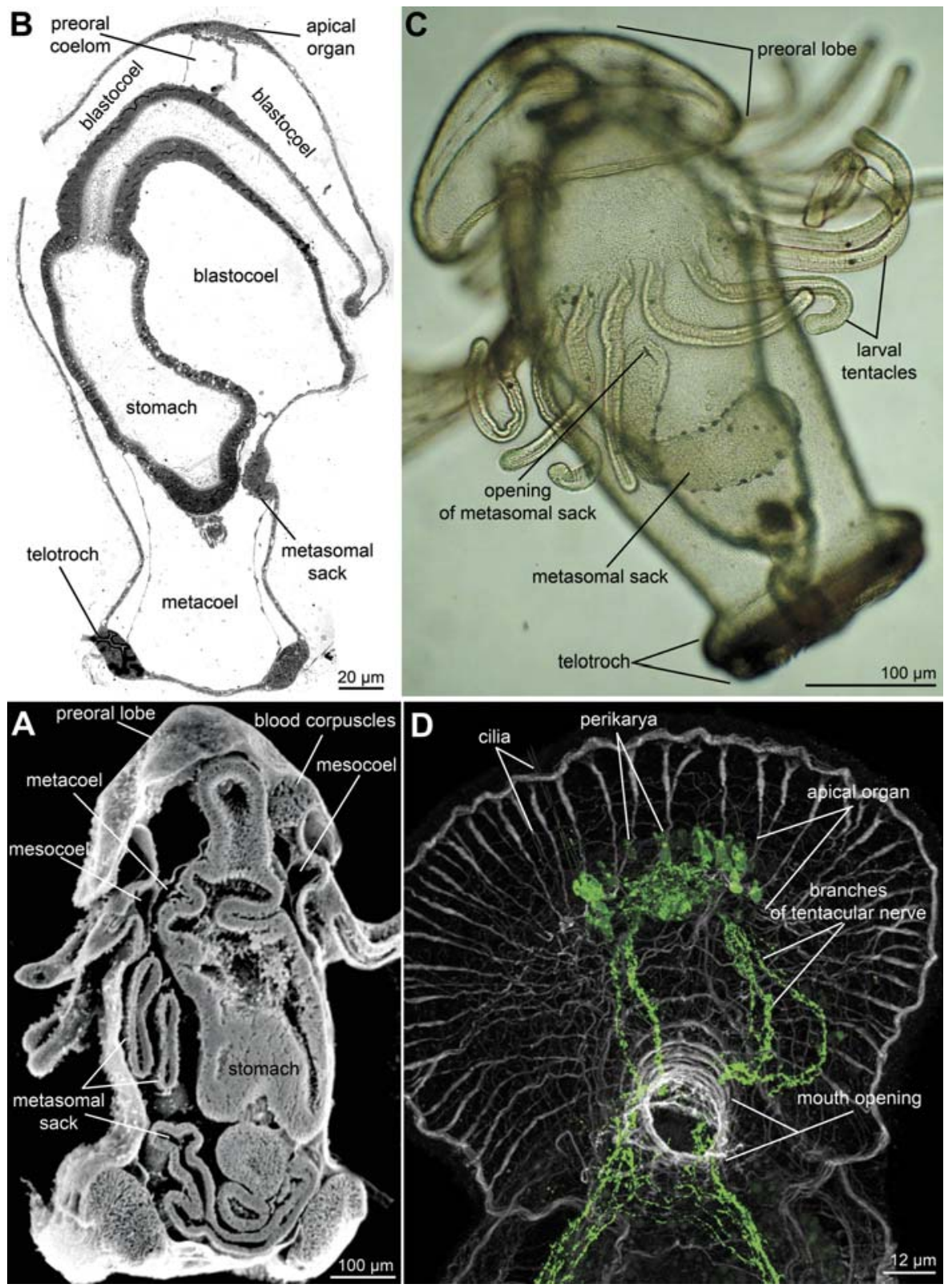

Fig. 2. Phoronid larvae.

A - Competent larva of Phoronipsis harmeri, frontal section, scanning electron microscopy (SEM); B - Young larva of Phoronipsis harmeri, sagittal semi-thin section; C — Live actinotrocha from Coos Bay (Oregon, USA, photograph courtesy of S. A. Maslakova); D - Z-projection of apical organ of a 24-day-old larva of Phoronopsis harmeri stained for 5HT and F-actin (mounted in Muray Clear). Green color — nervous system, gray color — muscles.

Рис. 2. Личинки форонид.

A - Компетентная личинка Phoronipsis harmeri, фронтальный срез, сканирующая электронная микроскопия (СЭМ); В - Молодая личинка Phoronipsis harmeri, сагиттальный полутонкий срез; С — Живая актинотроха из зал. кус Бэй (Орегон, США, любезно предосталена С.А. Маслаковой); D - Z-проекция переднего конца тела 24хдневной личинки Phoronipsis harmeri, окрашенной антителами против серотонина и фаллоидином (смотрирована в Muray Clear). Зеленый цвет - нервная система, серый цвет - мускулатура. 

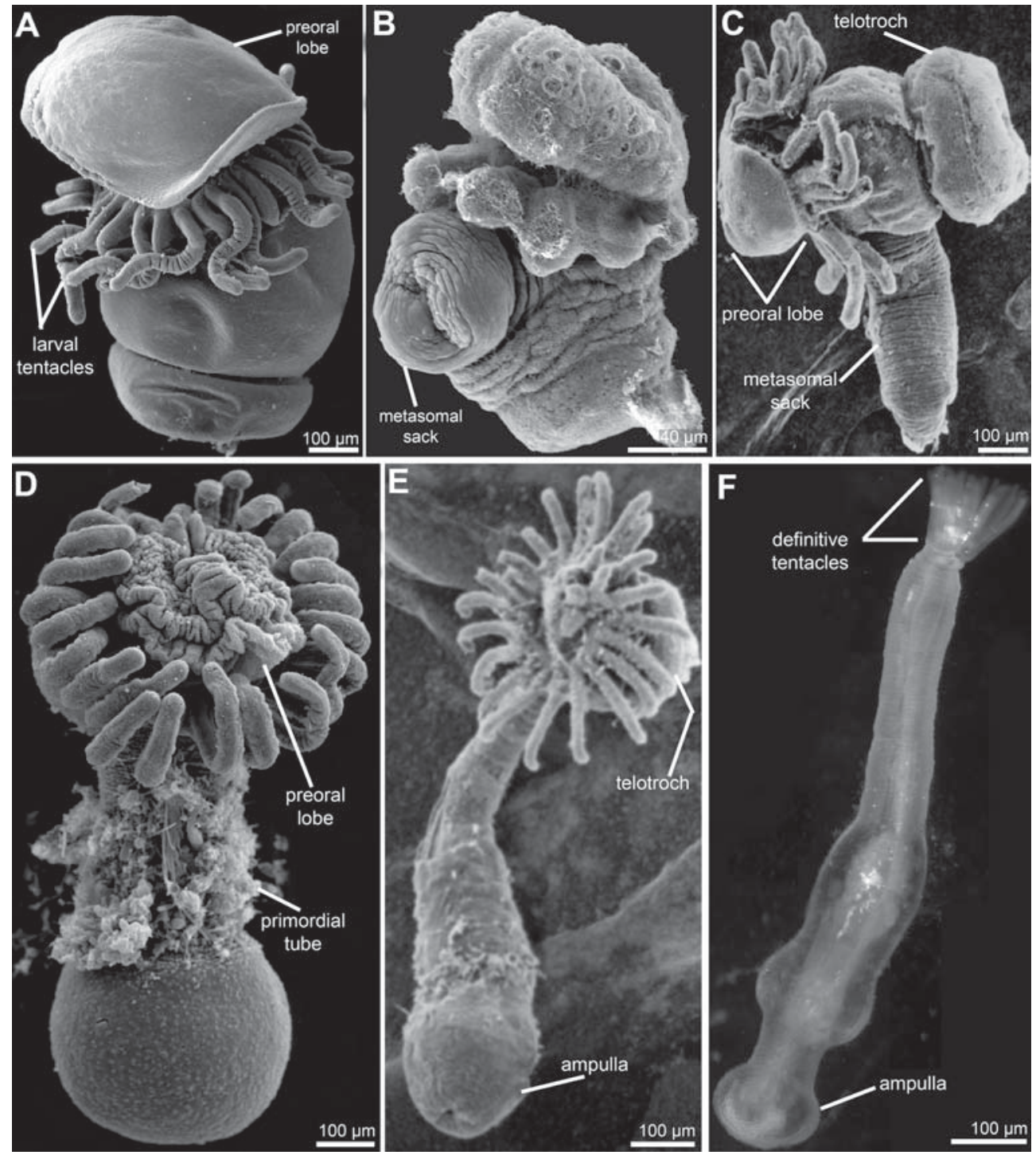

Fig. 3. Metamorphosis in phoronids. SEM (A-E) and light (F) micrographs.

A - Competent larva of Phoronopsis harmeri; B - Larva of Phoronis ijimai, the start of eversion of the metasomal sack; C - Larva of Phoronopsis harmeri with fully everted metasomal sack; D - The stage of maceration of the preoral lobe; E - The stage of formation of definitive tentacles from distal portions of larval tentacles; $\mathrm{F}$ - The juvenile of Phoronopsis harmeri.

Рис. 3. Метаморфоз форонид. Фотографии со сканирующего электронного микроскопа (А-Е) и светового стереоскопического микроскопа (F).

А — Компетентная личинка Phoronopsis harmeri; B — Личинка Phoronis ijimai, у которой начал выворачиваться метасомальный карман; C - Личинка Phoronopsis harmeri с полностью вывернутым метасомальным карманом; $\mathrm{D}$ - Стадия мацерации преоральной лопасти; $\mathrm{E}$ — Стадия формирования дефинитивных щупалец из дистальных концов личиночных щупалец; F - Ювениль Phoronopsis harmeri. 
forms into a thin protrusion. During the first 6 minutes of metamorphosis, the metasomal sack and larval oesophagus and stomach, and especially the upper portion of the stomach, stretch substantially. During the metamorphosis of Phoronopsis harmeri, the larval preoral lobe and distal parts of larval tentacles are macerated and digested (Fig. 3D, E). The dorsal body wall of the larva becomes very short and is located between the mouth and anus. After 15 minutes, the juvenile animal forms; only the presence of the telotroch indicates that it is not an adult animal. The telotroch breaks down and disappears after 9 days (Fig. 3F).

Thus, the body of the adult phoronid originates from the ventral body side of the larva (Fig. 4A). Adult phoronids have very long ventral sides and very short dorsal sides. The anterior-posterior axis passes from mouth to anus, and is also very short.

Do phoronids have any sign of metamery? It is well known that the trunk coelom in adult phoronids is subdivided into four cavities by five mesenteries (Fig. 4B). In addition to dorso-ventral mesentery, which occurs in all bilaterian animals, phoronids possess two lateral mesenteries (Fig. 4B). Their nature has been explained by the hypothesis of phoronid folding. This hypothesis presumes that a hypothetical ancestor of phoronids inhabited a U-shaped burrow in soft sediment, where it drew the anterior and posterior parts of the body together and eventually fused them (Mamkaev, 1962). As a consequence of folding, the paired coelomic sacks situated along the ascending and descending portions of the gut came into contact with each other and fused, forming the lateral mesenteries along the line of contact. However, peculiarities of phoronid metamorphosis and the position of the nephridial funnels on the lateral mesenteries are not explained by this elegant concept. The phoronid larva does not, strictly speaking, fold onto its dorsal side, becoming U-shaped. In fact, the protrusion of the larval ventral side has just developed (Fig. 4A).

We suggest an alternative hypothesis to explain the origin of lateral mesenteries in phoronids. According to this alternative hypothesis, the phoronid ancestors were oligomerous animals that possessed not only preoral and tentacular coelomes but also two coelomic compartments in the trunk (Fig. 4C). The paired nephridial funnels opened on a dissepiment between these coelomic compartments. This oligomerous ancestor buried itself in soft sediment by means of the ventral protrusion to which the loop of the intestine and dissepiment were drawn (Fig. 4C). We suggest that the lateral mesenteries of contemporary adult phoronids represent what became of the dissepiments between the anterior and posterior pairs of trunk coeloms (Fig. 4C). This also explains the position of the nephridial funnels.

Phoronids have oral, anal, interintestinal, and two lateral mesenteries (Temereva, Malakhov, 2001). The oral, anal, and interintestinal mesenteries are parts of the dorso-ventral mesentery, which is present in all coelomic Bilateria. The left and right lateral mesenteries are unique features of phoronids. Lateral mesenteries are situated at a right angle to the short anterior-posterior axis (Fig. 4B). This is consistent with the idea that the left and right mesenteries are parts of a dissepiment that divided two trunk segments. These segments have formed the body of recent phoronids (Fig. 4C). We emphasize that the epistomal coelom (if present) and the lophophoral coelom do not count as trunk segments.

The presence of metamery in phoronid can be supported by new data about early neurogenesis of Phoronopsis harmeri (Temereva, 2011). As it was shown, young Ph. harmeri larvae have ventral nerve cord, which consist of two rows of repetitive perikarya and cross commissures between paired perikarya. Thin repetitive commissures are apparent both in the serotonergic and FMRF-amidergic nervous system in young larvae. Phoronids may have inherited this nerve cord with metameric commissures from their common ancestor, which had a metameric organization.

\section{Why was metamery reduced in phoronids and brachiopods?}

The presence of metamery in phoronids and brachiopods correlates with their close relation 


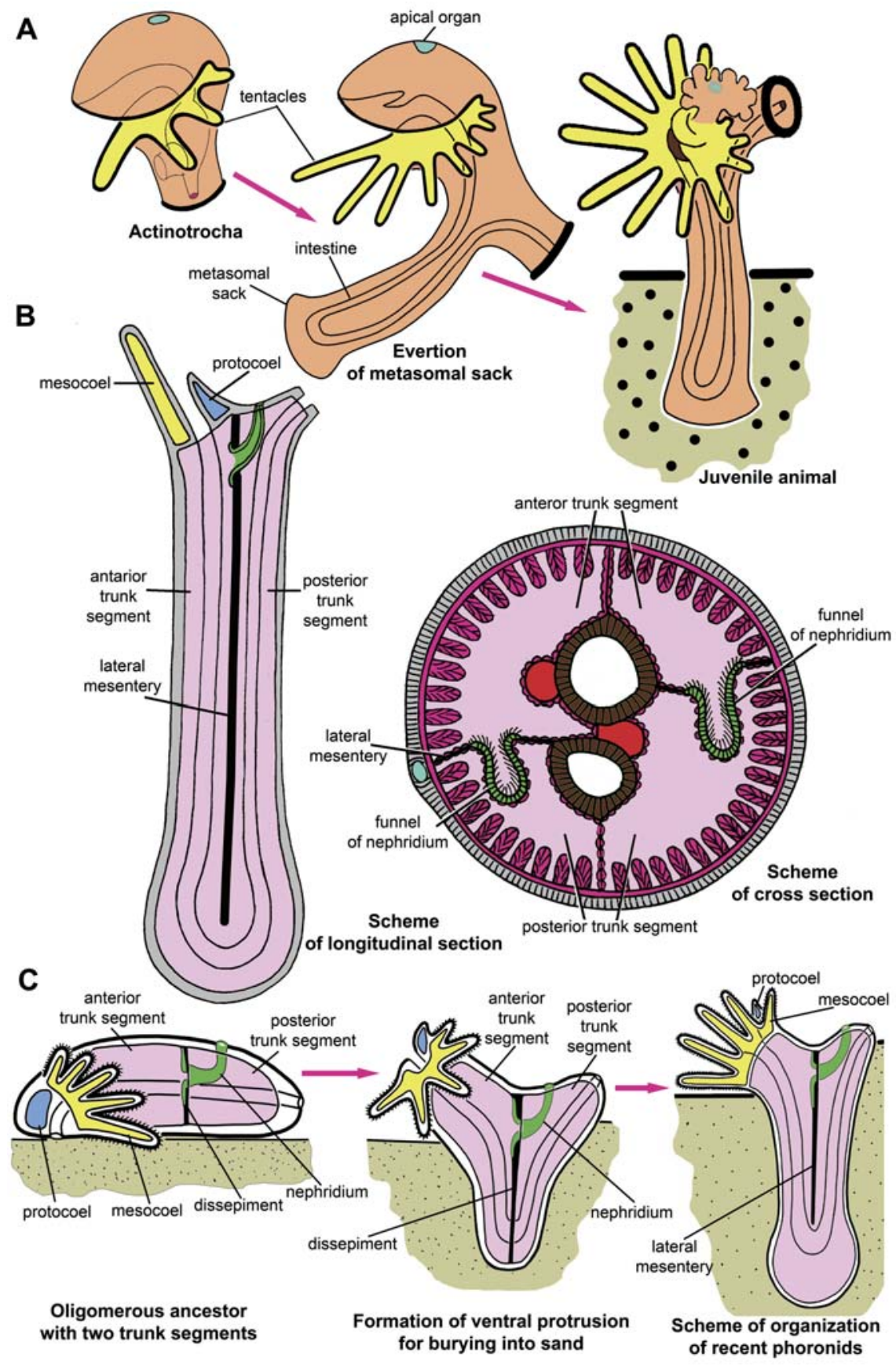

Fig. 4. Metamery in phoronids.

A - The scheme of phoronid metamorphosis; B - Schemes of longitudibal and transverse sections through the body of an adult phoronid; $\mathrm{C}$ - The origin of the phoronid body plan during evolution.

Рис. 4. Метамерия у форонид.

А - Схема метаморфоза форонид от актинотрохи до ювенильного животного; В — Схемы продольного (слева) и поперечного (справа) срезов через тело взрослой форониды; С - Происхождения плана строения форонид в эволюции. 
with the Trochozoa, in which the central group (the Annelida) has pronounced metamery. Primitive annelids are polymeric animals with a large number of segments. Annelida have a tendency toward oligomerization of segment number. Among annelids, oligomerous forms are small animals like Dinophilus, Ophriotrocha, and other Archiannelida. Living in tubes and burrows contributes to the loss of metamery. In some sedentary polychaets, the dissepiments in the anterior body part are partly reduced or absent. Adult sipunculans and echiurans, which are burrowing animals, do not have metamery. It is possible that reduction of dissepiments in sedentary polychaets, echiurans, and sipunculans correlates with peristaltic locomotion. If dissepiments remained, they would prevent movement of the coelomic fluid. In nonmetameric sipunculids and echiurids, detailed investigation of the nervous system has revealed metameric ganglions in the ventral nerve cord (Hessling, Westheide, 2002; Kristof et al., 2008; Wanninger, 2009). Like annelids, mollusks exhibit a reduction of metamery. In Polyplacophora, the metamery is expressed as metameric plates of the shell and metameric muscles (Dogiel, 1981; Ivanov et al., 1985). Monoplacophora has metameric ctenidia and nerve comissures. Moreover, monoplacophores have six pairs of nephridial, and this metamery is coordinated with metamery of the ctenidia. Other mollusks demonstrate partial or complete loss of metamery.

Brachiopods and phoronids are true metameric animals but are extremely oligomerous even in comparison with archiannelids or Mollusks. It is therefore reasonable to ask: "Why have brachiopods and phoronids retained so few segments?" The reduction in segments might correlate with a unique body plan. In both groups, the anterior-posterior axis (this is the axis of metamery) is extremely short(Figs 1,4). Though body plans of brachiopods and phoronids are variable in both groups, the main body axis (apical-basal axis) passes perpendicularly to the anterior-posterior axis.

In brachiopods, the anterior-posterior axis passes from the brachial valve to the pedicle valve, and this leaves sufficient space for only a small number of segments. In phoronids, the length of anterior-posterior axis relative to the apical-basal axis is even less than in brachiopods. This might explain why phoronids retained only two trunk segments.

In both groups, further loss of metamery is evident in some species. In adult craniids, for example, the gastroparietal mesentery is absent (Hyman, 1959). Among phoronids, Phoronis muelleri does not have a left lateral mesentery, and the tiny Phoronis ovalis lacks both the left and right mesenteries. In addition, neither of the lateral mesenteries in phoronids passes into the ampulla (Fig. 4B, C). The ampulla is the most mobile body part and can swell and contract (Fig. 3D-F). The reduction of lateral mesenteries in this body part facilitates movement of the coelomic fluid in the trunk cavity.

\section{Are Lophophorates primitive Lo- photrochozoa?}

The position of the Lophophorata on the phylogenetic tree of Lophotrochozoa is still a subject of intensive discussions. Some authors consider brachiopods and phoronids as the basal Lophotrochozoa (Zrzavý et al., 1998; Giribet et al., 2000; Peterson, Ernisse, 2001), while others place them among true Trochozoa (Giribet, 2008; Jang, Hwang, 2009; Paps et al., 2010). However, true Trochozoa (annelids, molluscks, nemertines, and entoprocts) have determined spiral cleavage of the egg and their coelom formation involves teloblasts (Render, 1997; Henry, Martindale, 1998; Boyer et al., 1998), whereas barchiopods and phoronids have radial undetermined cleavage of the egg and their coelom formation, like that of the deuterostomians, involves enterocoely (Malakhov, Temereva, 1999; Freeman, Martindale, 2002; Temereva, Malakhov, 2007).

How can this contradiction be solved? One possible solution is that brachiopods and phoronids lost spiral cleavage and develop radial cleavage and an enterocoelic manner of coelom formation independently of deuterostomians (Hausdorf et al., 2007, 2010; Dunn et al., 2008; Hejnol et al., 2009; Heinol, 2010). In that case, 


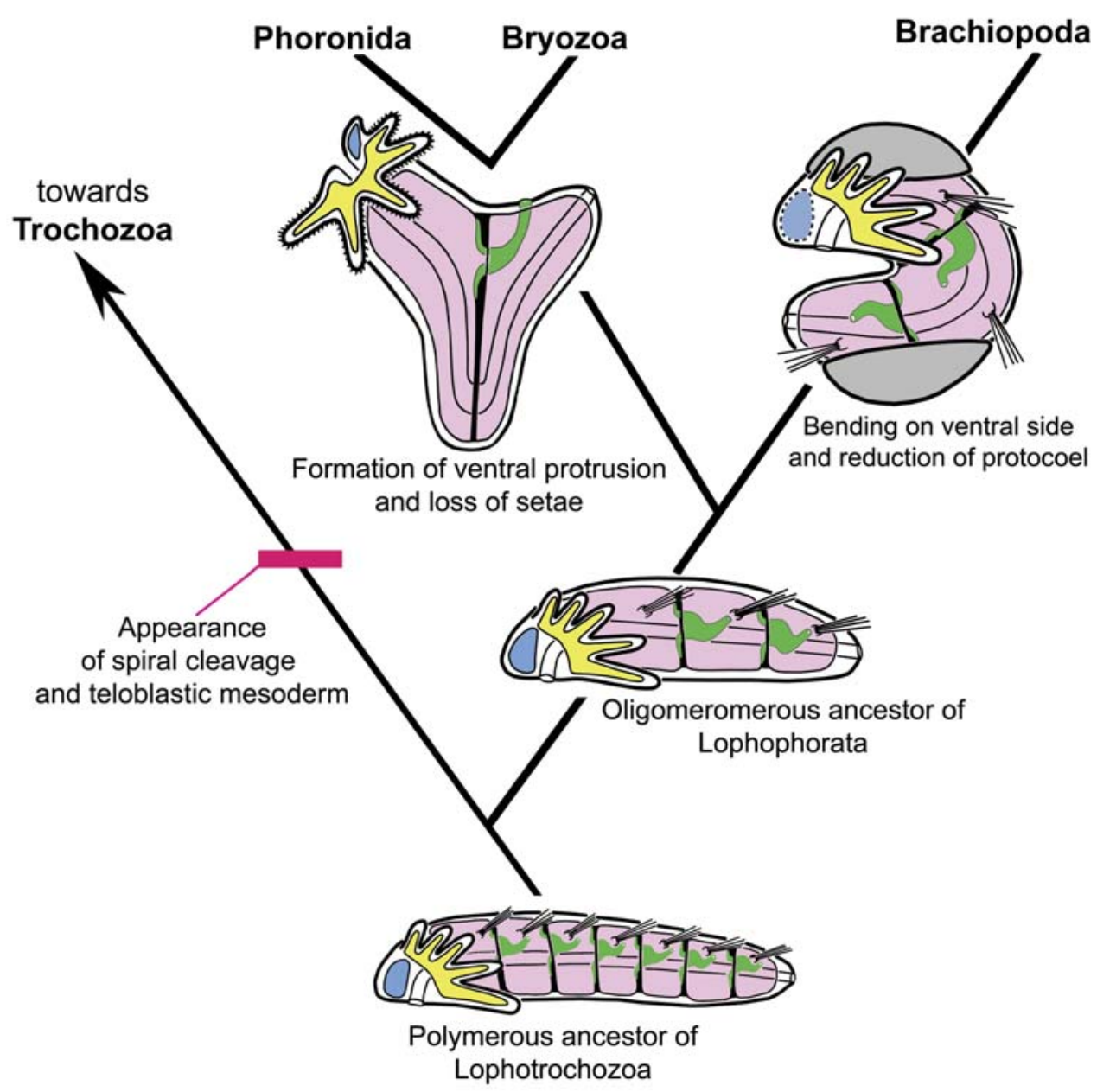

Fig. 5. Evolution of metamery in the stem Lophophorata.

Рис. 5. Эволюция метамерии лофофорат.

we have to concede that the radial cleavage and enterocoelic type of coelom formation originated at least twice: in deuterostomians and in lophophorates. It is more plausible that radial cleavage and enterocoely are plesiomorphic features that were characteristic for ancestral bilaterians. Deuterostomians, chaetognaths, and lophophorates have retained these plesiomorphic conditions, while spiralians developed determined spiral cleavage and teloblasts as a specific synapomorphy.

Some other aspects of lophophorates development also emphasize their primitive position in comparison with true Trochozoa. In phoronid and brachiopod development, their first signal neurons differentiate in the epidermis of the apical plate (Hay-Schmidt, 1990a; Altenburger, Wanninger, 2010) as they do in larvae of Deuterostomia: hemichordates and echinodermates (Hay-Schmidt, 2000; Tagawa et al., 2001; Dupont et al., 2009; Katow et al., 2009). Moreover, according to our unpublished data (Fig. 2D) and the published literature (Hay-Schmidt, 1990a, b; Sanatagata, 2002; Santagata, Zimmer, 2002), the apical organ of actinotrochs contains numerous serotonergic neurons. The apical organ of trochophores contains only two or four serotonergic neurons (Croll, Voronezhskaya, 1996; 
Voronezhskaya et al., 2002, 2003; Voronezhskaya, 2007). In larvae of annelids and mollusks, the first signal neurons differentiate in the posterior part of the body and do not connect with the apical plate (McDougall et al., 2006; Voronezhskaya, 2007). The decrease in number of neurons in the apical organ of Spiralia is derived condition in comparison with quantity of neurons in lophophorates and deuterostomians. The formation of the posterior nerve center seems to be a synapomorphy of Spiralia.

\section{Conclusion}

Because metamery occurs in all principal groups of Bilateria, we infer that the common bilaterian ancestor was a metameric animal. This hypothesized ancestor had metameric coelomic compartments that arose from chambers of the gastral cavity; it had simple, nondeterminate radial cleavage of the egg; it had multicellular enterocoelic origin of the coelomic mesoderm; and it had numerous nerve cells in the apical nerve center. Lophophorates retained most of these characters but they reduced the number of trunk segments drastically (Fig. 5). Metamery was nearly lost, we suggest, because the body plan in all lophophorates has strongly changed in different ways. Brachiopods have folded on the ventral side while phoronids formed a ventral protrusion (Fig. 5). In spite of these dramatic transformations of body plans, we are able to recognize the vestiges of the metamery in both brachiopods and phoronids, and these are the lateral mesenteries. They are situated at an angle to the main axis of the body and always at a right angle to the axis of metamery. Moreover, the lateral mesenteries in phoronids and brachiopods bear funnels of excretory organs like the dissepiments of true metameric animals. Thus, lophophorates are metameric animals like all other Bilateria.

\section{Acknowledgments}

Elena Temereva is very grateful to her friends Svetlana Maslakova and Gorge von Dassow for hosting her at the Oregon Institute of Marine
Biology and helping her to obtain interesting material about phoronid neurogenesis. We thank B. Jaffee for the help with English language. The project was funded by the Russian Foundation for Basic Research (11-04-00690), the Ministry of Education and Science of Russian Federation (contracts \#02.740.11.0875 and \#P727), and Grant of the President of Russia (MD-2892.2011.4). The participation of Vladimir Malakhov was supported by the Grant of the Government of Russian Federation No. 2010-220-01-180.

\section{References}

Adoutte A., Balavoine G., Lartillot N., Lespinet O., Prud'homme B., de Rosa R. 2000. The new animal phylogeny: reliability and implications // Proc. Natl. Acad. Sci. USA. Vol.97. P.4453-4456. (doi:10.1073/ pnas.97.9.4453)

Altenburger A., Wanninger A. 2010. Neuromuscular development in Novocrania anomala: evidence for the presence of serotonin and a spiralian-like apical organ in lecithotrophic brachiopod larvae // Evol. Dev. Vol.12. No.1. P.16-24.

Balavoine G., Adoutte A. 2003 The segmented Urbilateria: a testable scenario // Integr. Comp. Biol. Vol.43. P.137-147. (doi:10.1093/icb/43.1.137)

Bartolomaeus T. 2001. Ultrastructure and formation of the body cavity lining in Phoronis muelleri (Phoronida, Lophophorata) // Zoomorphology. Vol.120. No.3. P.135-148.

Blochmann F. 1892. Untersuchungen über den Bau der Brachiopoden. Pt.1. Die Anatomie von Crania anomala (Müller). Jena: Gustav Fischer. $65 \mathrm{~S}$.

Blochmann F. 1900. Untersuchungen über den Bau der Brachiopoden. Pt.2. Die Anatomie von Discinisca lamellosa (Broderip) und Lingula anatina (Bruguiére). Jena: Gustav Fischer. 124 S.

Boyer B.C., Henry J.J., Martindale M.Q. 1998. The cell lineage of a polyclad turbellarian embryo reveals close similarity to coelomate spiralians // Dev Biol. Vol.204. P.111-123.

Cohen B.L. 2000. Monophyly of brachiopods and phoronids: reconciliation of molecular evidence with Linnean classification (the subphylum Phoroniformea nov.) // Proc. R. Soc. L. Vol.267. No.1440. P.225231.

Cohen B., Weydmann A. 2005. Molecular evidence that phoronids are a subtaxon of brachiopods (Brachiopoda: Phoronata) and that genetic divergence of metazoan phyla began long before the early Cambrian // Organisms, Diversity and Evolution. Vol.5. P.253-273.

Croll R.P., Voronezhskaya E.E. 1996. Early elements in ga-stropod neurogenesis // Dev. Biol. Vol.173. P.344347. 
Cowles R.P. 1904. Origin and fate of the body-cavites and the nefridia of the Actinotrocha // Ann. Mag. Nat. Hist. Vol.14. P.69-78.

Dogiel V.A. 1981. [Invertebrate Zoology]. Moscow: Vysshaya Shkola. 1-560 p. [in Russian]

Dunn C. W. et al. 2008. Broad phylogenomic sampling improves resolution of the animal tree of life // Nature. Vol.452. P.745-749. (doi:10.1038/nature06614)

Dupont S., Thorndyke W., Thorndyke M.C., Burke R.D. 2009. Neural development of the brittlestar Amphiura filiformis // Dev. Genes Evol. Vol.219. P.159-166. (doi: 10.1007/s00427-009-0277-9)

Freeman G., Martindale M.Q. 2002. The origin of mesoderm in phoronids // Dev. Biol. Vol.252. P.301-311.

Giribet G. 2002 Current advances in the phylogenetic reconstruction of metazoan evolution. A new paradigm for the Cambrian explosion? // Mol. Phylogenet. Evol. Vol.24. P.345-357. (doi:10.1016/S10557903(02)00206-3)

Giribet G. 2008. Assembling the lophotrochozoan (=spiralian) tree of life // Phyl. Trans. Roy. Soc. Vol.363. P.1513-1522.

Giribet G., Distel D.L., Polz M., Sterrer W., Wheeler W.C. 2000 Triploblastic relationships with emphasis on the acoelomates and the position of Gnathostomulida, Cycliophora, Plathelminthes, and Chaetognatha: a combined approach of $18 \mathrm{~S}$ rDNA sequences and morphology // Syst. Biol. Vol.49. P.539-562. (doi:10.1080/10635159950127385)

Goodrich M.A. 1903. On the body-cavites and nefridia of the Actinotrocha larva // Quart. J. Mic. Sci. Vol.47. P.103-121.

Gruhl A., Grobe P., Bartolomaeus T. 2005. Fine structure of the epistome in Phoronis ovalis: significance for the coelomic organization in Phoronida // Invert. Biol. Vol.124. No.4. P.332-343.

Gutmann W.F., Vogel K., Zorn H. 1978. Brachiopods: biomechenical interdependences governing their origin and phylogeny // Science. Vol.199. P.890-893.

Halanych K.M. 2004 .The new view of animal phylogeny // Annu. Rev. Ecol. Evol. Syst. Vol.35. P.229-256. (doi:10.1146/annurev.ecolsys.35.112202.130124)

Halanych K.M., Passamaneck Y. 2001 A brief review of metazoan phylogeny and future prospects in Hoxresearch // Am. Zool. Vol.41. P.629-639. (doi:10.1668/ 0003-1569(2001)041[0629:ABROMP]2.0.CO;2)

Halanych K.M., Bacheller J.D., Aguinaldo A.M., Liva S.M., Hillis D.M., Lake J.A. 1995. Evidence from 18S ribosomal DNA that the lophophorates are protostome animals // Science. Vol.267. P.1641-1643. (doi:10.1126/science.7886451)

Hancock A. 1859. On the organization of the Brachiopodes // Philos. Trans. R. Soc. Vol.148. P.791-869.

Hausdorf B., Helmkampf M., Meyer A., Witek A., Herlyn H., Bruchhaus I., Hankeln T., Struck T.H., Lieb B. 2007. Spiralian phylogenomics supports the resurrection of Bryozoa comprising Ectoprocta and Entoprocta // Mol. Biol. Evol. Vol.24. P.2723-2729.

Hausdorf B., Helmkampf M., Nesnidal M.P., Bruchhaus I. 2010. Phylogenetic relationships within the lophophorate lineages (Ectoprocta, Brachiopoda and Phoronida) // Mol. Phylogenet. Evol. Vol.55. P.1121-1127.

Hay-Schmidt A. 1990. Catecholamine-containing, serotonin-lake and FMRFamide-like immunoreactive neurons and processes in the nervous system of the early actinotroch larva of Phoronis vancouverensis (Phoronida): distribution and development // Can. J. Zool. Vol.68. No.7. P.1525-1536.

Hay-Schmidt A. 1990. Distribution of catecholamine containing, serotonin-like and neuropeptide FMRFamidelike immunoreactive neurons and processes in the nervous system of the actinotroch larva of Phoronis muelleri (Phoronida) // Cell Tissue Res. Vol.259. P.105-118.

Hay-Schmidt A. 2000. The evolution of the serotonergic nervous system // Proc. R. Soc. Vol.267. P.1071-1079.

Hejnol A., et al. 2009. Assessing the root of bilaterian animals with scalable phylogenomic methods // Proc. Biol. Sci. Vol.276. P.4261-4270.

Hejnol A. 2010. A Twist in Time - the evolution of spiral cleavage in the Light of Animal Phylogeny // Integr. Compar. Biol. P.1-12. (doi:10.1093/icb/icq103).

Helfenbein K.G., Boore J.L. 2004. The mitochondrial genome of Phoronis architecta - comparisons demonstrate that phoronids are lophotrochozoan protostomes // Mol. Biol. Evol. Vol.21. P.153-157. (doi:10.1093/molbev/msh011)

Helmkampf M., Bruchhaus I., Hausdorf B. 2008. Phylogenomic analyses of lophophorates (brachiopods, phoronids and bryozoans) confirm the Lophotrochozoa concept // Proc. R. Soc. Vol.275. P.1927-1933.

Henry J.J., Martindale M.Q. 1998. Conservation of the spiralian developmental program: Cell lineage of the nemertean, Cerebratulus lacteus // Dev. Biol. Vol.201. P. 253-269.

Herrmann K. 1979. Larvalentwicklung und Metamorphose von Phoronis psammophila (phoronida, Tentaculata) // Helgol. Wiss. Meeresuntersuch. Bd.32. S.550-581.

Hessling R., Westheide W. 2002. Are Echiura derived from a segmented ancestor? - immunohistochemical analysis of the nervous system in developmental stages of Bonellia viridis // J. Morph. Vol.252. P.100-113.

Hyman L.H. 1959. The Invertebrates. Vol.5. Smaller Coelomate Groups. N. Y.: McCraw-Hill. P.516-609.

Ivanov A.V., Polyanskiy Yu.I., Strelkov A.A. 1985. [The greater practicum on invertebrate zoology]. Vol. 3. Moscow: Vysshaya Shkola. 390 p. [in Russian].

James M.A. 1997. Brachiopoda: Internal Anatomy, Embryology, and Development // Microscopic Anatomy of Invertebrates. Vol.13: Lophophorates, Entoprocta, and Cycliophora. N.Y.: Wiley-Liss, Inc. P.297-407.

Jang K.H., Hwang U.W. 2009. Complete mitochondrial genome of Bugula neritina (Bryozoa, Gymnolaemata, Cheilostomata): phylogenetic position of Bryozoa and phylogeny of lophophorates within the Lophotrochozoa // BMC Genomics. Vol.10. P.167-185.

Katow Y., Elia, L., Byrne M. 2009. Development of nervous systems to metamorphosis in feeding and 
non-feeding echinoid larvae, the transition from bilateral to radial symmetry // Dev Genes Evol. Vol.219. P.67-77. (doi: 10.1007/s00427-008-0266-4)

Kovalevsky À.Î. 1867. [Anatomy and Life History of Phoronis] // Proc. St. Petersburg Acad. Sci. Vol.2. P.1-35 [in Russian].

Kristof A., Wollesen T., Wanninger A. 2008. Segmental Mode of Neural Patterning in Sipuncula // Current Biol. Vol.18. No.15. P.1129-1132.

Kuzmina T., Malakhov V., Temereva E. 2006. [Anatomy of coelomic system in the articulate brachiopoda Hemithyris psittacea (Brachiopoda, Articulata)] // Zool. Zhurn. Vol.85. No.9. P.1118-1128 [in Russian].

Kuzmina T., Malakhov V. 2011. The periesophageal coelom of the articulate brachiopod Hemithyris psittacea (Brachiopoda, Articulata) // J. Morphol. Vol.272. No.2. P.180-190.

Lüter C. 2000. The origin of the coelom in Brachiopoda and its phylogenetic significance // Zoomorphology. Vol.120. P.15-28. (doi:10.1007/s004359900019).

Lüter C. 2004. Tentaculata im phylogenetischen System der Bilateria - gehören sie zu den Radialia oder den Lophotrochozoa? // Sitz.-ber. Ges. Naturf. Freunde Berlin. Bd.43. S.1-21.

Lüter C., Bartolomaeus T. 1997. The phylogenetic position of Brachiopoda - a comparison of morphological and molecular data // Zool. Scr. Vol.26. P.245254. (doi:10.1111/j.1463-6409.1997.tb00414.x).

Malakhov V., Kuzmina T. 2006. Metameric origin of lateral mesenteries in Brachiopoda // Dokl. Biol. Sci. Vol.409. No.5. P.1-3.

Malakhov V.V., Temereva E.N. 1999. Embryonic development of the Phoronid Phoronis ijimai (Lophophorata, Phoronida): two sources of the coelomic mesoderm // Dokl. Biol. Sci. Vol.365. P.166-168.

Mamkaev Yu.V. 1962. [About Phoronids of Far Eastern Seas] // Issledovaniya dal'nevostochnykh morei SSSR. Leningrad. Vol.8. P.219-237 [in Russian].

Masterman A.T. 1898. On the Diplochorda // Quart. J. Mic. Sci. Vol.40. P.281-366.

McDougall C., Chen W.-Ch., Shimeld S.M., Ferrier D. 2006. The development of the larval nervous system, musculature and ciliary bands of Pomatoceros lamarckii (Annelida): heterochrony in polychaetes // Front. Zool. Vol.3. No.16 (doi:10.1186/1742-9994-3-16).

Menon K.R. 1902. Notes of Actinotrocha // Quart. J. Mic. Sci. Vol.45. P.473-484.

Nesnidal M.P., Helmkampf M., Hausdorf B. 2010. Compositional heterogeneity and phylogenomic Inference of metazoan relationships // Mol. Biol. Evol. Vol.27. No.9. P.2095-2104.

Nielsen C. 1991. The development of the brachiopod Crania (Neocrania) anomala (O. F. Mueller) and its phylogenetic significance // Acta Zool. Vol.72. P.728.

Paps J., Baguñà J., Riutort M. 2009. Bilaterian Phylogeny: a broad sampling of 13 nuclear genes provides a new Lophotrochozoa phylogeny and supports a paraphyletic basal acoelomorpha // Mol. Biol. Evol. Vol.26. No.10. P.2397-2406.
Paps J., Baguñà J., Riutort M. 2010. Lophotrochozoa internal phylogeny: new insights from an up-to-date analysis of nuclear ribosomal genes // Proc. R. Soc. (doi:10.1098/rspb.2008.1574).

Peterson K.J., Eernisse D.J. 2001 Animal phylogeny and the ancestry of bilaterians: inferences from morphology and 18S rDNA gene sequences // Evol. Dev. Vol.3. P.170-205. (doi:10.1046/j.1525-142x.2001. 003003170.x)

Remane A. 1949. Die Entstehung der Metamerie der Wirbellosen // Verh. Deutsche Zool. Ges. in Mainz / Zool. Anz. Suppl. Bd.42. S.16-23.

Render J. 1997. Cell fate maps in the Ilyanassa obsoleta embryo beyond the third division// Dev. Biol. Vol.189. P.301-310.

Rouse G.W., Fauchald K. 1997. Cladistics and polychaetes // Zool. Scripta. Vol.26. No.2. P.139-204.

Santagata S. 2002. Structure and metamorphic remodeling of the larval nervous system and musculature of Phoronis pallida (Phoronida) // Evol. Dev. Vol.4. P.28-42.

Santagata S., Zimmer R.L. 2002. Comparison of the neuromuscular system among actinotroch larvae: systematic and evolutionary implication // Evol. Dev. Vol.4. P.43-54.

Siewing R. 1974. Morphologische Untersuchungen zum Archicoelomatenproblem. The body segmentation in Phoronis muelleri de Selys-Longchamps (Phoronidea) Ontogenese - Larve - Metamorphose - Adultus // Zool. Jahrb. Anat. Bd.92. H.2. S.275-318.

Siewing R. 1980. Das Archicoelomatenkonzept // Zool. Jahrb., Anat. Ontog. Bd.103. S.439-482.

Telford M.J. 2006 Animal phylogeny // Curr. Biol. Vol.16. P.981-985. (doi:10.1016/j.cub.2006.10.048).

Temereva E.N. 2010. The digestive tract of actinotroch larvae (Lophotrochozoa, Phoronida): anatomy, ultrastructure, innervations, and some observations of metamorphosis// Can. J.Zool. Vol.88. No.12. P.11491168.

Temereva E.N. 2011. Ventral nerve cord in Phoronopsis harmeri larvae // JEZ Part B: Molecular and Developmental Evolution. Vol.314B. (doi: 10.1002/jez.b. 21437).

Temereva E.N., Malakhov V.V. 2001. The morphology of the Phoronid Phoronopsis harmeri // Russ. J. Mar. Biol. Vol.27. No.1. P.21-30.

Temereva E.N., Malakhov V.V. 2006. [The answer to Thomas Bartolomaeus: "Larva of phoronid Phoronopsis harmeri Pixell, 1912 has trimeric coelom organization"] // Invert. Zool. Vol.2. No.2. P.394-402 [in Russian].

Temereva E.N., Malakhov V.V. 2007. Embryogenesis and larval development of phoronid Phoronopsis harmeri Pixell, 1912: dual origin of the coelomic mesoderm // Invert. Reprod. Dev. Vol.50. No.2. P. 57-66.

Temereva E.N., Malakhov V.V. 2011. Organization of the epistome in Phoronopsis harmeri (Phoronida) and consideration of the coelomic organization in Phoronida // Zoomorphology. Vol.130. P.121-134. 
Ulrich W. 1951. Vorschläge zu einer Revision der Großeinteilung des Tierreiches//Verh. DeutscheZool. Ges., Marburg. S.244-271.

Voronezhskaya E.E., Tyurin S.A., Nezlin L.P. 2002. Neuronal development in larval chiton Ischnochiton hakodadensis (Mollusca: Polyplacophora) // J. Comp. Neurol. Vol.444. P.25-38.

Voronezhskaya E.E., Tsitrin E.B., Nezlin L.P. 2003. Neuronal development in larval polychaete Phyllodoce maculata (Phyllodocidae)// J. Comp. Neurol. Vol.455. P.299-309.

Voronezhskaya E.E. 2007. [Early neurogenesis of Trochozoa: appearance and function of transitory neurons] // Biologiya Razvitiya. Vol.2. No.4. P.73-77 [in Russian].
Wanninger A., Kristof A., Brinkmann N. 2009. Sipunculans and segmentation // Communicative \& Integrative Biol. Vol.2. No.1. P.56-59

Williams A., James M.A., Emig C.C., Mackay S., Rhodes M.C. 1997. Anatomy // R.L. Kaesler (ed.). Treatise on Invertebrate Paleontology. Part H. Brachiopoda. Vol.1. Introduction. Boulder (Colorado), Lawrence: Geological Society of America \& The University of Kanzas. (Kansas). P.7-189.

Zrzavý J., Mihulka S., Kepka P., Bezdek A., Tietz D. 1998 Phylogeny of the Metazoa based on morphological and 18 S ribosomal DNA evidence//Cladistics. Vol.14. P.249-285. (doi:10.1006/clad.1998.0070).

Responsible editor K.G. Mikhailov 